\title{
HUBUNGAN PENERAPAN ETIKA PERKANTORAN DAN SIKAP PELAYANAN PRIMA TENAGA ADMINISTRASI SEKOLAH DENGAN KEPUASAN PESERTA DIDIK
}

\author{
Mohammad Yusuf Tri Handoko \\ Agus Timan \\ Desi Eri Kusumaningrum
}

\author{
email:mohammad.yusufth@gmail.com \\ Universitas Negeri Malang, Jl. Semarang No. 5 Malang 65145
}

\begin{abstract}
The purpose of this study was to explained the relation between the application of the office ethics and the excellent services of the school administration personnel for the students's satisfaction rate at Junior High School in Bantur Malang. This study used quantitative approach and the type of research was correlational descriptive. Data collection method used closed questionnaire. The data analysis was consist of: (1) descriptive analysis; (2) product moment pearson correlation analysis; and (3) double correlation. The result of this study indicates that there was a significant relaton between the application of the office ethics and the excellent services of the school administration personnel in giving services for the students's satisfaction.
\end{abstract}

Keywords: office ethic, excellent services, students's satisfaction

\begin{abstract}
Abstrak: Tujuan utama adanya penelitian ini adalah untuk menjelaskan hubungan antara penerapan etika perkantoran dan pelayanan prima tenaga administrasi sekolah dengan kepuasan peserta didik SMP Negeri di Kecamatan Bantur Kabupaten Malang. Penelitian ini menggunakan pendekatan kuantitatif dan jenis penelitian yang digunakan adalah deskriptif korelasional. Teknik pengumpulan data penelitian dengan menggunakan angket tertutup. Analisis data dalam penelitian ini terdiri atas: (1) analisis deskriptif; (2) analisis korelasi product moment pearson; dan (3) korelasi ganda. Hasil dari penelitian ini menunjukkan bahwa terdapat hubungan yang signifikan antara penerapan etika perkantoran dan pelayanan prima tenaga administrasi sekolah dalam memberikan pelayanan dengan kepuasan peserta didik.
\end{abstract}

Kata kunci: etika perkantoran, pelayanan prima, kepuasan peserta didik

Dunia pendidikan pada masa ini diharapkan menggunakan model pengelolaan pendidikan berbasis industri, dimana pengelolaan model ini mengandaikan adanya upaya pihak pengelola industri pendidikan untuk meningkatkan mutu pendidikan berdasarkan manajemen perusahaan. Pelaku pengelolaan pendidikan dalam hal ini adalah para tenaga administrasi sekolah yang melakukan tata administrasi di lembaga pendidikan. Tata administrasi merupakan suatu wadah dan penyalur antara pelanggan pendidikan dan pelaku pendidikan. Pelanggan yang dimaksud dalam hal ini adalah masyarakat yang berkepentingan dengan lembaga pendidikan, khususnya warga sekolah dan orangtua yang menyekolahkan anaknya pada suatu lembaga pendidikan atau sekolah. Pelayanan administrasi membutuhkan tenaga administrasi sekolah yang kompeten dan memiliki keterampilan untuk memberikan pelayanan yang baik agar dapat memberikan kepuasan bagi para pelanggan pendidikan. 
Standar kompetensi yang dimiliki oleh pegawai tenaga administrasi sekolah berbeda antara satu dengan yang lainnya sesuai dengan kebutuhan lembaga pendidikan yang bersangkutan. Dalam Peraturan Menteri Pendidikan Nasional Republik Indonesia Nomor 24 Tahun 2008 tentang Standar Tenaga Administrasi Sekolah, kompetensi yang harus dimiliki meliputi "kompetensi kepribadian, kompetensi sosial, kompetensi teknis, dan kompetensi manajerial". Keterampilan pegawai tenaga administrasi sekolah pada umumnya sama, keterampilan yang dimaksud, seperti cara berpakaian, cara berkomunikasi, menerima tamu, pelayanan cepat dan tepat, serta memberikan pelayanan secara konsisten.

Masa sekarang hendaknya tenaga administrasi sekolah harus memperhatikan kualitas pelayanan pendidikan yang mereka berikan. Kualitas pelayanan pendidikan itu sendiri berkaitan dengan perbandingan antara kualitas jasa yang dipersepsikan dan diterima pelanggan dengan apa yang mereka harapkan. Sehingga untuk mencapai kualitas pelayanan yang baik tersebut Zulkarnain \& Sumarsono (2011:151), mengemukakan bahwa "dalam memberikan pelayanan hendaknya tenaga administrasi sekolah mendengarkan dan memperhatikan dengan baik para pelanggan sehingga dapat memberikan pelayanan yang baik dan mampu menciptakan kepuasan pada pelanggan pendidikan".

Berdasarkan hal tersebut, pegawai administrasi supaya meningkatkan pelayanannya termasuk tentang penerapan etika perkantoran dan pelayanan prima. Menurut Zulkarnain \& Sumarsono (2011:64) adalah "etika berasal dari bahasa Yunani ethichos yang berarti norma, aturan, kaidah, nilai tingkah laku manusia yang baik". Sedangkan Riady (2008:189) menjelaskan, bahwa "etika dalam bahasa Latin diartikan sebagai moralis yang berasal dari kata mores dengan makna adat-istiadat yang realistis bukan teoritis". Pengertian etiket tersendiri menurut Zulkarnain \& Sumarsono (2011:64) etiket berasal dari bahasa Perancis etiquette yang berarti kartu undangan raja yang memuat tata tertib para tamu raja". Sedangkan menurut Wursanto (2006:39) menjelaskan, bahwa "etiket juga diartikan sebagai tata krama dan sopan-santun yang baik dalam menggunakan bahasa maupun dalam tingkah laku dimana etiket ini lebih ditekankan pada sikap dan perbuatan yang lebih bersifat jasmaniah atau lahiriah". Menurut Kasmir (2005:80) mengatakan "etiket sebagai suatu tindakan yang mengatur tingkah laku atau perilaku manusia dalam bermasyarakat". Sedangkan menurut Bratawidjaja (1992:243), "etika adalah ilmu pengetahuan azas-azas akhlak atau moral. Sasaran etika adalah moralitas, yaitu agar seseorang dapat membedakan apa yang baik dan apa yang tidak baik". Menurut Zulkarnain \& Sumarsono (2014:84) kewajiban atau prinsip pokok dalam rangka mewujudkan etika service work di kantor sekolah yaitu: 1 . ESToMaT untuk semua: akronim dari Empat 'S' (senyum, sapa, salam, santun) Tolong, Maaf, dan Terima kasih. 2. Cepat dan Tepat. Pelayanan kantor harus memenuhi dua kriteria ini sekaligus, layanan yang tepat tidak boleh lama dan sebaliknya layanan yang tepat juga tidak boleh salah.

Zulkarnain \& Sumarsono (2014:89) menyatakan bahwa untuk menjalankan tugas memberikan pelayanan sebaik-baiknya kepada para tamu, maka penerima tamu harus memenuhi persyaratan sebagai berikut. 1. Sopan, ramah tamah, berkepribadian menarik, berbusana rapi dan profesional. 2. Bijaksana dan cerdas dalam mengambil keputusan dan bertindak. 3. Mengetahui apa yang boleh dan apa yang tidak boleh dibicarakan dengan tamu. 4. Mengetahui struktur organisasi dan nama-nama pejabat atau pimpinan sekolah. 5. Sebaiknya mampu berbicara bahasa asing terutama bahasa Inggris.

Widyaiswara (2009:1) menyatakan "pelayanan prima merupakan terjemahan istilah excellent services yang secara harfiah berarti pelayanan terbaik atau sangat baik. Disebut sangat baik atau terbaik karena sesuai dengan standar pelayanan yang berlaku atau dimiliki instansi pemberi layanan". "Prima atau excellent yang berarti bermutu tinggi dan memuaskan" (Rendang, 2013:1). Dari beberapa pengertian tersebut dapat disimpulkan bahwa pelayanan prima adalah kegiatan memberikan pelayanan terbaik untuk mengutamakan kepuasan pelanggan. Dalam memberikan pelayanan prima sebagai usaha untuk mencapai kepuasan pelanggan, sebuah instansi dapat berpedoman pada variabel-variabel pelayanan prima menurut Barata (2004:31) meliputi "kemampuan (ability), sikap (attitude), penampilan (appearance), perhatian (attention), tindakan (action), dan tanggungjawab (accountability)".

Perilaku-perilaku demikian sangat berpengaruh terhadap kepuasan pelanggan. Jika tenaga administrasi sekolah memberikan pelayanan yang memuaskan, maka akan berdampak pada kepuasan pelanggan yang meningkat. Namun jika sebaliknya, maka pelanggan akan merasa kurang puas dan 
akan berkeluh kesah terhadap pelayanan yang telah diberikan. Menurut Tse \& Wilton (dalam Tjiptono, 2014:353) menyatakan, bahwa "kepuasan/ketidakpuasan pelanggan sebagai respon pelanggan terhadap evaluasi ketidaksesuaian (disconfirmation) yang dipersepsikan antara harapan awal sebelum pembelian (atau norma kinerja lainnya) dan kinerja aktual produk yang dipersepsikan setelah pemakaian atau konsumsi produk bersangkutan".

Lovelock \& Wright (2007:102), menyatakan "konsumen mengalami berbagai tingkat kepuasan atau ketidakpuasan setelah mengalami masing-masing jasa sesuai dengan sejauh mana harapan mereka terpenuhi atau terlampaui. Kepuasan merupakan keadaan emosional, reaksi pasca-pembelian mereka dapat berupa kemarahan, ketidakpuasan, kejengkelan, netralitas, kegembiraan, atau kesenangan". Sedangkan Sumarwan (2004:322) menyatakan, bahwa "kepuasan dan ketidakpuasan konsumen merupakan dampak dari perbandingan antara harapan konsumen sebelum pembelian dengan yang sesungguhnya diperoleh konsumen dari produk yang dibeli tersebut".

Kepuasan pelanggan merupakan suatu tingkat perasaan pelanggan setelah pelanggadn membandingkan kinerja dengan harapan yang diinginkannya. Setiap pelanggan memiliki tingkat kepuasan yang berbeda satu sama lain. Pada dasarnya pengertian kepuasan pelanggan mencakup adanya perbedaan antara tingkat kepentingan dan kinerja yang ada dengan hasil yang akan diharapkan dan dirasakannya (Gunawan, 2012:1).

Tujuan penelitian ini untuk: (1) mendeskripsikan tingkat penerapan etika perkantoran tenaga administrasi sekolah SMP Negeri di Kecamatan Bantur Kabupaten Malang; (2) mendeskripsikan tingkat penerapan pelayanan prima tenaga administrasi sekolah SMP Negeri di Kecamatan Bantur Kabupaten Malang; (3) mendeskripsikan tingkat kepuasan peserta didik atas layanan yang diberikan oleh tenaga administrasi sekolah SMP Negeri di Kecamatan Bantur Kabupaten Malang; (4) menjelaskan hubungan penerapan etika perkantoran tenaga administrasi sekolah dengan kepuasan peserta didik SMP Negeri di Kecamatan Bantur Kabupaten Malang; (5) menjelaskan hubungan penerapan pelayanan prima tenaga administrasi sekolah dengan kepuasan peserta didik SMP Negeri di Kecamatan Bantur Kabupaten Malang; dan (6) menjelaskan hubungan antara penerapan etika perkantoran dan pelayanan prima tenaga administrasi sekolah dengan kepuasan peserta didik SMP Negeri di Kecamatan Bantur Kabupaten Malang.

\section{METODE}

Penelitian ini menggunakan pendekatan penelitian kuantitatif yang bersifat deskriptif korelasional. Dalam penelitian ini menggunakan Model korelasional Multivariat. Variabel dalam penelitian ini menggunakan dua variabel bebas dan satu variabel terikat. Variabel dalam penelitian ini, yaitu Penerapan Etika Perkantoran (X1) sebagai variabel bebas 1, Penerapan Pelayanan Prima (X2) sebagai variabel bebas 2 dan Tingkat Kepuasan Peserta Didik (Y) sebagai variabel terikat. Populasi dalam penelitian ini sebanyak 943 peserta didik yang berada di SMP Negeri 1 Bantur, SMP Negeri 2 Bantur, SMP Negeri 3 Bantur, SMP Negeri 4 Bantur Satu Atap, dan SMP Negeri 5 Bantur Satu Atap. Sedangkan sampel dalam penelitian ini sebanyak 280 peserta didik. Instrumen penelitian ini berupa angket secara tertutup. Angket tertutup adalah angket yang disusun dengan menyediakan pilihan jawaban lengkap, dan responden memberikan jawabannya dengan memberi tanda check list $(\sqrt{ })$ pada alternatif pilihan jawaban yang dianggap sesuai atau tepat. Pengukuran skala menggunakan Skala Likert. Cara menguji kelayakan instrumen penelitian menggunakan uji validitas Product Moment Pearson dan uji reliabilitas Alpha Cronbach.

Penganalisisan data pada penelitian ini menggunakan analisis deskriptif, uji asumsi dasar, dan pengujian hipotesis. Analisis deskriptif menjelaskan mengenai kategori yang dimiliki oleh variabel penerapan etika perkantoran, penerapan pelayanan prima, dan kepuasan peserta didik baik kategori tinggi, sedang, dan rendah. Uji asumsi dasar menggunakan uji normalitas dan uji homogenitas. Uji normalitas digunakan untuk mengetahui apakah data dalam penelitian berdistribusi normal atau tidak. Uji normalitas dalam penelitian ini menggunakan Kolmogorov-Smirnov Z. Uji homogenitas dilakukan untuk melihat dan mengatahui apakah varian dari populasi memiliki nilai yang sama atau tidak. Tujuannya 
adalah untuk mengetahui apakah ada perbedaan atau tidak dari suatu kelompok atau kumpulan sampel. Pengujian hipotesis dalam penelitian ini dilakukan dengan menggunakan teknik analisis korelasi. Tujuan teknik analisis korelasi adalah untuk mengetahui hubungan antara satu variabel dengan variabel lainnya. Maka untuk mengetahui hubungan antara satu variabel dengan variabel lainnya ini menggunakan teknik analisis korelasi Product Moment Pearson.

\section{HASIL}

\section{Tingkat Internalisasi Etika Perkantoran Tenaga Administrasi Sekolah}

Data tentang penerapan etika perkantoran yang diterapkan oleh tenaga administrasi sekolah SMPN di Kecamatan Bantur diperoleh melalui angket tertutup dengan 19 butir pernyataan yang diberikan kepada peserta didik SMPN di Kecamatan Bantur. Jumlah responden yang diteliti, yaitu sebanyak 280 peserta didik. Berdasarkan hasil analisis deskriptif variabel penerapan etika perkantoran (X1) SMPN di Kecamatan Bantur Kabupaten Malang, menunjukkan bahwa variabel X1 memperoleh nilai minimum $=45$, maximum $=95$, mean $=80,71$, dan standart deviation ( simpangan baku) $=8,594$. Kelas interval dari variabel penerapan etika perkantoran (X1) yang mempunyai 19 butir pernyataan, diperoleh nilai maksimum dikurangi nilai minimum (95 - 45) dibagi banyaknya kelas interval (4) yang hasilnya adalah 12,50 dibulatkan menjadi 12. Secara rinci kelas interval varibel penerapan etika perkantoran dapat dilihat dalam Tabel 1.

Tabel 1 Distribusi Frekuensi Variabel Etika Perkantoran

\begin{tabular}{ccccc}
\hline No & Klasifikasi & Interval & Frekuensi & Persentase (\%) \\
\hline 1 & Sangat rendah & $45-56$ & 7 & 2,50 \\
2 & Rendah & $57-68$ & 19 & 6,78 \\
3 & Tinggi & $69-80$ & 94 & 33,58 \\
4 & Sangat tinggi & $>81$ & 160 & 57,14 \\
\hline & Jumlah & $\mathbf{2 8 0}$ & 100 \\
\hline
\end{tabular}

Berdasarkan Tabel 1 menunjukkan bahwa dari 280 peserta didik sebagai responden, sebanyak 7 peserta didik termasuk dalam klasifikasi sangat rendah dengan persentase $2,50 \%$ yang berarti bahwa tenaga administrasi sekolah tidak menerapkan etika perkantoran, 19 peserta didik termasuk dalam klasifikasi rendah dengan persentase $6,78 \%$ yang berarti bahwa tenaga administrasi sekolah kurang menerapkan etika perkantoran, 94 peserta didik termasuk dalam klasifikasi tinggi dengan persentase 33,58\% yang berarti bahwa tenaga administrasi sekolah telah menerapkan etika perkantoran dengan baik, 160 peserta didik termasuk dalam klasifikasi sangat tinggi dengan persentase $57,14 \%$ yang berarti bahwa tenaga administrasi sekolah telah menerapkan etika perkantoran dengan sangat baik. Nilai mean atau ratarata dari variabel penerapan etika perkantoran adalah sebesar 80,71 yang berada pada kategori sangat tinggi, sehingga dapat disimpulkan bahwa menurut perspektif peserta didik, para tenaga administrasi sekolah telah menerapkan etika perkantoran dengan sangat baik ketika memberikan pelayanan kepada peserta didik SMPN di Kecamatan Bantur Kabupaten Malang. Berikut diagram distribusi penerapan etika perkantoran oleh tenaga administrasi sekolah pada Gambar 1 Diagram Persentase Variabel Etika Perkantoran.

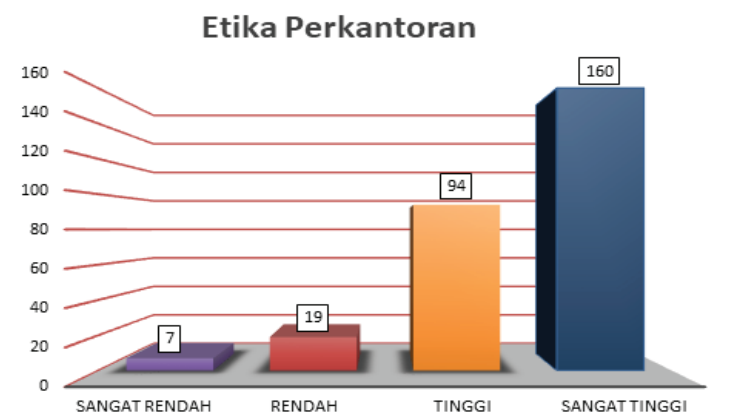

Gambar 1 Diagram Persentase Variabel Etika Perkantoran 


\section{Tingkat Penerapan Sikap Pelayanan Prima Tenaga Administrasi Sekolah}

Data tentang penerapan pelayanan prima yang diterapkan oleh tenaga administrasi sekolah SMPN di Kecamatan Bantur diperoleh melalui angket tertutup dengan 21 butir pernyataan yang diberikan kepada peserta didik SMPN di Kecamatan Bantur. Jumlah responden yang diteliti, yaitu sebanyak 280 peserta didik. Berdasarkan hasil analisis deskriptif variabel penerapan pelayanan prima (X2) SMPN di Kecamatan Bantur Kabupaten Malang, menunjukkan bahwa variabel X2 memperoleh nilai minimum = 48 , maximum $=105$, mean $=87,91$, dan standart deviation $($ simpangan baku) $=8,749$. Kelas interval dari variabel penerapan pelayanan prima (X2) yang mempunyai 21 butir pernyataan, diperoleh nilai maksimum dikurangi nilai minimum (105 - 48) dibagi banyaknya kelas interval (4) yang hasilnya adalah 14,25 dibulatkan menjadi 14. Secara rinci kelas interval varibel penerapan pelayanan prima dapat dilihat dalam Tabel 2 Distribusi Frekuensi Variabel Pelayanan Prima.

Tabel 2 Distribusi Frekuensi Variabel Pelayanan Prima

\begin{tabular}{|c|c|c|c|c|}
\hline No & Klasifikasi & Interval & Frekuensi & Persentase (\%) \\
\hline 1 & Sangat rendah & $48-61$ & 1 & 0,36 \\
\hline 2 & Rendah & $62-75$ & 26 & 9,28 \\
\hline 3 & Tinggi & $76-89$ & 113 & 40,36 \\
\hline 4 & Sangat tinggi & $>90$ & 140 & 50 \\
\hline & Jumlah & & 280 & 100 \\
\hline
\end{tabular}

Berdasarkan Tabel 2 menunjukkan bahwa dari 280 peserta didik sebagai responden, sebanyak 1 peserta didik termasuk dalam klasifikasi sangat rendah dengan persentase $0,36 \%$ yang berarti bahwa tenaga administrasi sekolah tidak menerapkan pelayanan prima, 26 peserta didik termasuk dalam klasifikasi rendah dengan persentase $9,28 \%$ yang berarti bahwa tenaga administrasi sekolah kurang menerapkan pelayanan prima, 113 peserta didik termasuk dalam klasifikasi tinggi dengan persentase $40,36 \%$ yang berarti bahwa tenaga administrasi sekolah telah menerapkan pelayanan prima dengan baik, 140 peserta didik termasuk dalam klasifikasi sangat tinggi dengan persentase $50 \%$ yang berarti bahwa tenaga administrasi sekolah telah menerapkan pelayanan prima dengan sangat baik. Nilai mean atau rata-rata dari variabel penerapan pelayanan prima adalah sebesar 87,91 yang berada pada kategori tinggi, sehingga dapat disimpulkan bahwa menurut perspektif peserta didik, para tenaga administrasi sekolah telah menerapkan pelayanan prima dengan baik ketika memberikan pelayanan kepada peserta didik SMPN di Kecamatan Bantur Kabupaten Malang. Berikut diagram distribusi penerapan pelayanan prima oleh tenaga administrasi sekolah pada Gambar 2.

\section{Pelayanan Prima}

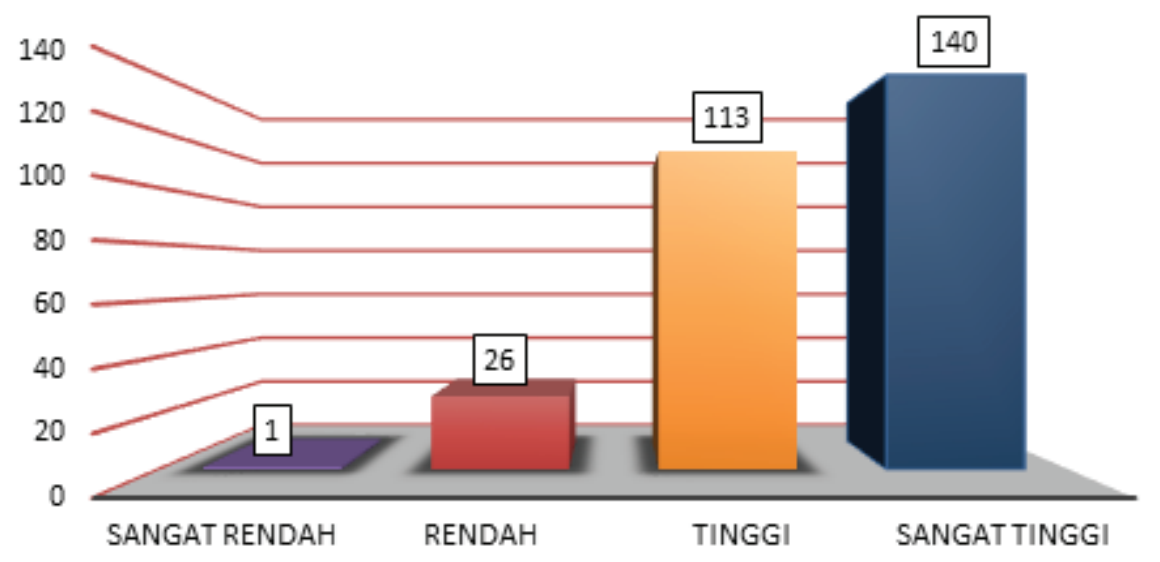

Gambar 2 Diagram Persentase Variabel Pelayanan Prima 


\section{Tingkat Kepuasan Peserta Didik atas Layanan yang diberikan oleh Tenaga Administrasi Sekolah}

Data tentang kepuasan peserta didik diperoleh melalui angket tertutup dengan 16 butir pernyataan yang diberikan kepada peserta didik SMPN di Kecamatan Bantur Kabupaten Malang. Jumlah responden yang diteliti, yaitu sebanyak 280 peserta didik. Berdasarkan hasil analisis deskriptif variabel kepuasan peserta didik (Y) SMPN di Kecamatan Bantur Kabupaten Malang, menunjukkan bahwa variabel Y memperoleh nilai minimum $=35$, maximum $=80$, mean $=67,24$, dan standart deviation (simpangan baku) $=7,073$. Kelas interval dari variabel kepuasan peserta didik $(\mathrm{Y})$ yang mempunyai 16 butir pernyataan, diperoleh nilai maksimum dikurangi nilai minimum (80 - 35) dibagi banyaknya kelas interval (4) yang hasilnya adalah 11,25 dibulatkan menjadi 11 . Secara rinci kelas interval varibel penerapan pelayanan prima dapat dilihat dalam Tabel 3.

Tabel 3 Distribusi Frekuensi Variabel Kepuasan Peserta Didik

\begin{tabular}{ccccc}
\hline No & Klasifikasi & Interval & Frekuensi & Persentase (\%) \\
\hline 1 & Sangat rendah & $35-45$ & 1 & 0,36 \\
2 & Rendah & $46-56$ & 24 & 8,57 \\
3 & Tinggi & $57-67$ & 103 & 36,79 \\
4 & Sangat tinggi & $>68$ & 152 & 54,28 \\
\hline & Jumlah & & 280 & 100 \\
\hline
\end{tabular}

Berdasarkan Tabel 3 menunjukkan bahwa dari 280 peserta didik sebagai responden, sebanyak 1 peserta didik termasuk dalam klasifikasi sangat rendah dengan persentase $0,36 \%$ yang berarti bahwa peserta didik tidak puas terhadap pelayanan yang diberikan oleh tenaga administrasi sekolah, 24 peserta didik termasuk dalam klasifikasi rendah dengan persentase $8,57 \%$ yang berarti bahwa peserta didik kurang puas terhadap pelayanan yang diberikan oleh tenaga administrasi sekolah, 103 peserta didik termasuk dalam klasifikasi tinggi dengan persentase 36,79\% yang berarti bahwa peserta didik merasa puas terhadap pelayanan yang diberikan oleh tenaga administrasi sekolah, 152 peserta didik termasuk dalam klasifikasi sangat tinggi dengan persentase 54,28\% yang berarti bahwa peserta didik merasa sangat puas terhadap pelayanan yang diberikan oleh tenaga administrasi sekolah. Nilai mean atau ratarata dari variabel kepuasan peserta didik adalah sebesar 67,24 yang berada pada kategori tinggi, sehingga dapat disimpulkan bahwa secara umum peserta didik merasa puas terhadap pelayanan yang diberikan oleh tenaga administrasi sekolah SMPN di Kecamatan Bantur Kabupaten Malang. Diagram distribusi variabel kepuasan peserta didik oleh tenaga administrasi sekolah dapat dilihat pada Gambar 3 Diagram Persentase Variabel Kepuasan Peserta Didik.

\section{Kepuasan Peserta Didik}

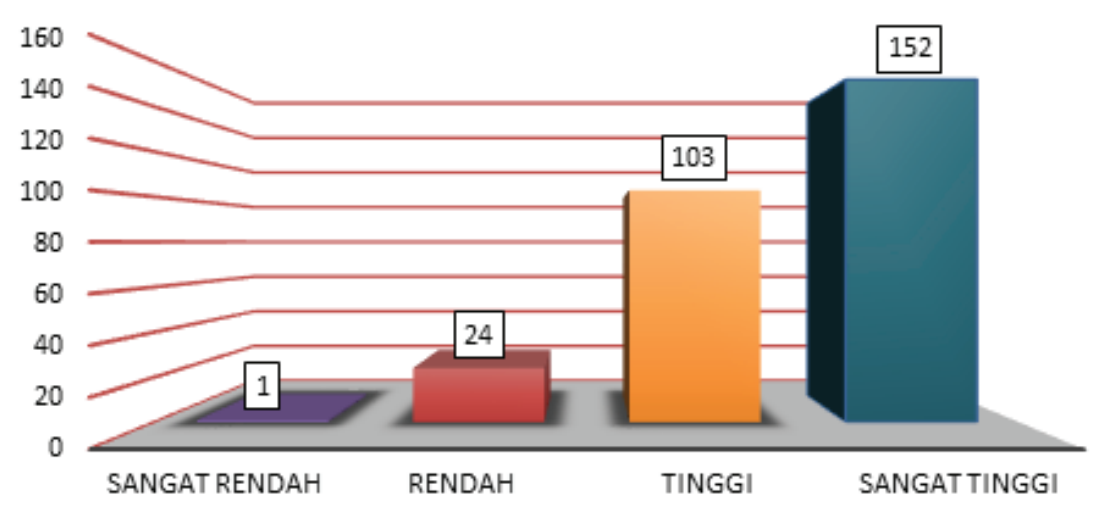

Gambar 3 Diagram Persentase Variabel Kepuasan Peserta Didik 


\section{PEMBAHASAN}

\section{Tingkat Penerapan Etika Perkantoran Tenaga Administrasi}

Berdasarkan hasil deskripsi data tingkat penerapan etika perkantoran tenaga administrasi sekolah menunjukkan bahwa dari 280 peserta didik sebagai responden, sebanyak 7 peserta didik termasuk dalam klasifikasi sangat rendah dengan persentase 2,50\% yang berarti bahwa tenaga administrasi sekolah tidak menerapkan etika perkantoran, 19 peserta didik termasuk dalam klasifikasi rendah dengan persentase $6,78 \%$ yang berarti bahwa tenaga administrasi sekolah kurang menerapkan etika perkantoran, 94 peserta didik termasuk dalam klasifikasi tinggi dengan persentase $33,58 \%$ yang berarti bahwa tenaga administrasi sekolah telah menerapkan etika perkantoran dengan baik, 160 peserta didik termasuk dalam klasifikasi sangat tinggi dengan persentase $57,14 \%$ yang berarti bahwa tenaga administrasi sekolah telah menerapkan etika perkantoran dengan sangat baik. Etika perkantoran itu sendiri pada dasarnya merupakan kaidah atau acuan yang digunakan manusia dalam bertingkah laku dan aturan yang mengatur bagaimana manusia bertingkah laku baik maupun buruk di dalam lingkungan organisasi kantor. Seperti yang dikemukakan oleh Bratawidjaja (1992:243), "etika adalah ilmu pengetahuan azas-azas akhlak atau moral. Sasaran etika adalah moralitas, yaitu agar seseorang dapat membedakan apa yang baik dan apa yang tidak baik". Etika perkantoran itu sendiri mencakup beberapa aspek, yaitu: penerapan etika menerima tamu dan penerapan etika memberikan pelayanan. Penerapan etika memberikan pelayanan dipengaruhi langsung oleh tenaga administrasi sekolah yang memberikan pelayanan tersebut. Tenaga administrasi sekolah yang melayani peserta didik harus memiliki kemampuan melayani pelanggan secara cepat dan tepat. Selain hal tersebut tenaga administrasi sekolah juga harus memiliki kemampuan sopan santun, ramah dan bertanggung jawab penuh terhadap pelanggan, serta memiliki pengetahuan dan kemampuan yang baik dalam memahami kebutuhan pelanggan. Seperti yang dikemukakan oleh Dewi (2008:18), bahwa sekretaris haruslah memenuhi syarat-syarat berikut ini: "(1) memiliki dedikasi yang tinggi terhadap segala tugas; (2) memiliki kepribadian menarik; (3) memiliki sensitivitas tinggi terhadap situasi dan kondisi lingkungan kerja; (4) memiliki kemampuan melakukan pendelegasian tugas kepada bawahan serta motivasi mereka secara bijaksana".

\section{Tingkat Penerapan Sikap Pelayanan Prima Tenaga Administrasi}

Berdasarkan hasil deskripsi data tingkat penerapan sikap pelayanan prima tenaga administrasi sekolah menunjukkan bahwa dari 280 peserta didik sebagai responden, sebanyak 1 peserta didik termasuk dalam klasifikasi sangat rendah dengan persentase $0,36 \%$ yang berarti bahwa tenaga administrasi sekolah tidak menerapkan pelayanan prima, 26 peserta didik termasuk dalam klasifikasi rendah dengan persentase $9,28 \%$ yang berarti bahwa tenaga administrasi sekolah kurang menerapkan pelayanan prima, 113 peserta didik termasuk dalam klasifikasi tinggi dengan persentase $40,36 \%$ yang berarti bahwa tenaga administrasi sekolah telah menerapkan pelayanan prima dengan baik, 140 peserta didik termasuk dalam klasifikasi sangat tinggi dengan persentase $50 \%$ yang berarti bahwa tenaga administrasi sekolah telah menerapkan pelayanan prima dengan sangat baik. Hal tersebut didapat karena tenaga administrasi sekolah menerapkan pelayanan prima dengan baik ketika memberikan pelayanan kepada peserta didik SMPN di Kecamatan Bantur Kabupaten Malang. Hal ini dibuktikan dengan penerapan sikap oleh tenaga administrasi sekolah berada pada kategori tinggi, penerapan perhatian oleh tenaga administrasi sekolah berada pada kategori tinggi, dan penerapan tindakan oleh tenaga administrasi sekolah berada pada kategori setuju.

Pelayanan tersebut berkaitan dengan melayani pelanggan berdasarkan penampilan yang sopan dan serasi, melayani pelanggan dengan berpikiran positif dan logis, serta melayani pelanggan dengan sikap menghargai. Seperti yang dikemukakan oleh Zulkarnain dan Sumarsono (2011:151) mengatakan, bahwa "pelayanan prima berdasarkan konsep attitude (sikap) yang meliputi tiga prinsip, yaitu: berpenampilan yang sopan dan serasi meliputi berhias, berbusana, ekspresi wajah, ekspresi mata, ekspresi mulut, dan ekspresi kepala; berpikiran positif dan logis; serta bersikap menghargai”. Penerapan perhatian oleh tenaga administrasi sekolah dalam hal ini berkaitan dengan sikap kepedulian tenaga administrasi sekolah terhadap pelanggan (peserta didik). Pelanggan akan lebih tertarik jika para tenaga administrasi di lembaga yang bersangkutan bersikap penuh perhatian terhadap pelanggan (peserta didik). Perhatian 
tersebut dapat diwujudkan dalam bentuk mendengarkan dan memahami kebutuhan pelanggan, mengamati perilaku pelanggan, dan mencurahkan perhatian penuh kepada pelanggan. Hal ini senada dengan pernyataan Zulkarnain dan Sumarsono (2011:151) bahwa "unsur yang harus diperhatikan ketika memberikan perhatian kepada pelanggan meliputi: mendengarkan (listening); perilaku (behavior); dan mencurahkan perhatian penuh kepada pelanggan". Penerapan tindakan pelayanan prima bertujuan agar peserta didik yang menerima pelayanan oleh tenaga administrasi sekolah dapat merasa puas atas pelayanan yang diberikan.

\section{Tingkat Kepuasan Peserta Didik atas Layanan yang Diberikan oleh Tenaga Administrasi}

Berdasarkan hasil deskripsi data tingkat kepuasan peserta didik atas layanan yang diberikan oleh tenaga administrasi sekolah menunjukkan bahwa dari 280 peserta didik sebagai responden, sebanyak 1 peserta didik termasuk dalam klasifikasi sangat rendah dengan persentase $0,36 \%$ yang berarti bahwa peserta didik tidak puas terhadap pelayanan yang diberikan oleh tenaga administrasi sekolah, 24 peserta didik termasuk dalam klasifikasi rendah dengan persentase $8,57 \%$ yang berarti bahwa peserta didik kurang puas terhadap pelayanan yang diberikan oleh tenaga administrasi sekolah, 103 peserta didik termasuk dalam klasifikasi tinggi dengan persentase $36,79 \%$ yang berarti bahwa peserta didik merasa puas terhadap pelayanan yang diberikan oleh tenaga administrasi sekolah, 152 peserta didik termasuk dalam klasifikasi sangat tinggi dengan persentase 54,28\% yang berarti bahwa peserta didik merasa sangat puas terhadap pelayanan yang diberikan oleh tenaga administrasi sekolah.

Hal tersebut didapat karena tingkat penerapan etika perkantoran dan pelayanan prima tenaga administrasi sekolah SMPN di Kecamatan Bantur Kabupaten Malang berada pada kategori sangat tinggi dan tinggi. Untuk meningkatkan tingkat kepuasan peserta didik perlu pula meningkatkan tingkat penerapan etika perkantoran dan pelayanan prima dari tenaga administrasi sekolah. Munculnya kepuasan dapat disebabkan oleh beberapa faktor. Mulai dari kualitas produk, hingga biaya atau kemudahan untuk mendapatkan produk atau jasa. Kepuasan pelanggan dapat muncul akibat satu faktor atau karena beberapa faktor, tergantung persepsi dari masing-masing pelanggan. Faktor-faktor pendorong kepuasan kepada pelanggan menurut Irawan (2007:37), antara lain sebagai berikut: (1) kualitas produk, (2) harga, (3) kualitas jasa, (4) emotional factor, dan (5) biaya atau kemudahan untuk mendapatkan produk atau jasa".

\section{Hubungan Penerapan Etika Perkantoran dengan Kepuasan Peserta Didik}

Dari hasil pengujian hipotesis pertama mengatakan, terdapat hubungan yang signifikan antara penerapan etika perkantoran tenaga administrasi sekolah dalam memberikan pelayanan dengan kepuasan peserta didik SMPN di Kecamatan Bantur Kabupaten Malang. Hasil analisis korelasi product moment pearson menunjukkan, bahwa nilai signifikansi $0,000<0,05$ sehingga $\mathrm{H} 0$ ditolak. Variabel penerapan ertika perkantoran $(\mathrm{X} 1)$ berpengaruh secara positif terhadap variabel kepuasan peserta didik (Y), karena hasilnya positif yaitu 0,654 . Dari hasil korelasi itu dapat dinyatakan kuat yang artinya variabel penerapan etika perkantoran tenaga administrasi sekolah memiliki hubungan terhadap variabel kepuasan peserta didik dan berpengaruh secara signifikan.

Hal tersebut didapat karena etika perkantoran merupakan hal yang perlu dipahami dalam pelaksanaan pengelolaan dan pelaksanaan tugas-tugas perkantoran sehingga dapat menciptakan hubungan kerjasama yang harmonis dan dapat mencapai tujuan perkantoran secara efektif dan efisien. Etika perkantoran dalam penelitian ini meliputi etika komunikasi kantor dan etika menerima tamu. Sebuah kantor memerlukan komunikasi yang baik agar kegiatan perkantoran dapat berjalan dengan baik. Seperti yang dikemukakan oleh Garnis (2011:1) menyatakan, bahwa "seorang manajer kantor harus dapat berkomunikasi secara efektif dengan semua pegawai kantor baik secara horizontal maupun vertikal atau secara diagonal. Pengurusan informasi yakni penyampaian dan penerimaan berita, akan berjalan dengan baik bila dalam kantor itu terdapat komunikasi yang efektif". Pendapat yang dikemukakan oleh Garnis di atas menunjukkan, bahwa komunikasi yang efektif akan menciptakan iklim kerja kantor yang sehat dan terbuka. Hal ini sangat penting guna meningkatkan kreativitas dan dedikasi para pegawai kantor. 


\section{Hubungan Pelayanan Prima dengan Kepuasan Peserta Didik}

Dari hasil pengujian hipotesis kedua mengatakan, bahwa terdapat hubungan yang signifikan antara penerapan pelayanan prima para tenaga administrasi sekolah dalam memberikan pelayanan dengan kepuasan peserta didik SMPN di Kecamatan Bantur Kabupaten Malang. Hasil analisis korelasi product moment pearson 0 menunjukkan, bahwa nilai signifikansi $0,000<0,05$ sehingga $\mathrm{H} 0$ ditolak. Variabel penerapan pelayanan prima (X2) berpengaruh secara positif terhadap variabel kepuasan peserta didik (Y), karena hasilnya positif yaitu 0,751 . Dari hasil korelasi itu dapat dinyatakan kuat yang artinya variabel penerapan pelayanan prima tenaga administrasi sekolah memiliki hubungan terhadap variabel kepuasan peserta didik dan berpengaruh secara signifikan.

Menurut Zukarnain \& Sumarsono (2014:107) menyatakan, bahwa pelayanan adalah tindakan atau perbuatan yang ditawarkan oleh satu pihak kepada pihak lain yang bersifat tidak kasat mata (intangible) dan tidak menghasilkan kepemilikan sesuatu. Sedangkan pengertian prima menunjukkan karakteristik total dari suatu produk (barang atau jasa) yang melebihi standar baku sehingga pelanggan merasa mendapat lebih dari yang semula diharapkan. Sedangkan menurut Widyaiswara (2009:1) menyatakan "pelayanan prima merupakan terjemahan istilah excellent services yang secara harfiah berarti pelayanan terbaik atau sangat baik. Disebut sangat baik atau terbaik karena sesuai dengan standar pelayanan yang berlaku atau dimiliki instansi pemberi layanan".

\section{Hubungan Penerapan Etika Perkantoran dan Pelayanan Prima dengan Kepuasan Peserta Didik}

Dari hasil pengujian hipotesis ketiga menyatakan bahwa terdapat hubungan yang signifikan antara penerapan etika perkantoran dan pelayanan prima tenaga administrasi sekolah dalam memberikan pelayanan dengan kepuasan peserta didik SMP Negeri di Kecamatan Bantur Kabupaten Malang. Nilai korelasi ganda sebesar 0,759 dan Fh sebesar 187,919 lebih besar dari Ft yaitu 3,028366 maka dapat dinyatakan bahwa korelasi ganda tersebut signifikan. Sehingga terdapat korelasi positif antara penerapan etika perkantoran dan pelayanan prima tenaga administrasi sekolah dengan kepuasan peserta didik SMP Negeri di Kecamatan Bantur Kabupaten Malang.

Pengertian kepuasan adalah perasaan senang para pelanggan yang menunjukkan, bahwa tujuan yang diinginkan sesuai dengan kenyataan yang ada di lapangan. Hal ini senada dengan pendapat yang disampaikan oleh Tjiptono (2015:78) bahwa, "jika kinerja lebih rendah daripada harapan, yang terjadi adalah ketidakpuasan emosional (negative disconfirmation). Bila kinerja lebih besar dibandingkan harapan, kepuasan emosional yang terjadi (positive disconfirmation). Sedangkan bila kinerja sama dengan harapan, maka yang terjadi adalah konfirmasi harapan (simple disconfirmation atau non-satisfaction)". Kepuasan dipengaruhi oleh etika yang diterapkan dan pelayanan yang diberikan oleh tenaga administrasi sekolah. Penjelasan tersebut sesuai dengan pendapat yang dikemukakan oleh Gunawan (2012:1), bahwa "salah satu faktor yang menentukan kualitas pelayanan perguruan tinggi ataupun lembaga lainnya adalah kemampuan dalam memberikan pelayanan yang berkualitas bagi pengguna jasa/pelanggan". Pendapat tersebut menunjukkan, bahwa pelayanan yang berkualitas merupakan pelayanan yang dilakukan dengan menerapkan etika perkantoran dan pelayanan prima. apabila etika perkantoran dan pelayanan prima diterapkan pada saat memberikan pelayanan, maka akan memberikan kontribusi positif terhadap kepuasan peserta didik sehingga hal ini juga akan memberikan kondisi yang baik bagi proses kerja serta kinerja tenaga administrasi sekolah SMP Negeri di Kecamatan Bantur Kabupaten Malang. Etika perkantoran dan pelayanan prima apabila diterapkan secara efektif, maka akan memberikan situasi dan interaksi yang akan membawa kebaikan dan kemajuan dalam rangka pencapaian tujuan organisasi.

Penerapan etika perkantoran dan pelayanan prima terhadap kepuasan peserta didik mempunyai hubungan signifikansi positif yang berarti bahwa penerapan etika perkantoran dan pelayanan prima yang semakin tinggi maka tingkat kepuasan peserta didik akan tinggi pula. Penerapan etika perkantoran dan pelayanan prima yang baik oleh tenaga adminsitrasi sekolah dapat meningkatkan tingkat kepuasan peserta didik di sekolah menengah pertama negeri di Kecamatan Bantur Kabupaten Malang. Maka penerapan etika perkantoran dan pelayanan prima sangat penting dalam mempengaruhi kepuasan peserta didik agar semakin meningkat. 


\section{KESIMPULAN DAN SARAN}

\section{Kesimpulan}

Kesimpulan pada penelitian ini adalah: (1) tingkat penerapan etika perkantoran para tenaga administrasi sekolah SMP Negeri di Kecamatan Bantur Kabupaten Malang berada pada kategori sangat tinggi yang berarti menurut peserta didik, tenaga administrasi sekolah telah menerapkan etika perkantoran dengan baik; (2) tingkat penerapan pelayanan prima para tenaga administrasi sekolah SMP Negeri di Kecamatan Bantur Kabupaten Malang berada pada kategori tinggi yang berarti menurut peserta didik, tenaga administrasi sekolah telah menerapkan pelayanan prima dengan baik; (3) tingkat kepuasan peserta didik atas pelayanan yang diberikan oleh tenaga administrasi sekolah SMP Negeri di Kecamatan Bantur Kabupaten Malang berada pada kategori tinggi yang berarti bahwa peserta didik merasa puas atas pelayanan yang diberikan; (4) ada hubungan yang signifikan antara penerapan etika perkantoran dengan kepuasan peserta didik SMP Negeri di Kecamatan Bantur Kabupaten Malang; (5) ada hubungan yang signifikan antara penerapan pelayanan prima dengan kepuasan peserta didik SMP Negeri di Kecamatan Bantur Kabupaten Malang; dan (6) ada hubungan yang signifikan antara penerapan etika perkantoran dan pelayanan prima dengan kepuasan peserta didik SMP Negeri di Kecamatan Bantur Kabupaten Malang.

\section{Saran}

Berdasarkan kesimpulan dalam penelitian ini, maka disarankan bagi: (1) tenaga administrasi sekolah SMP Negeri di Kecamatan Bantur Kabupaten Malang yang secara langsung memberikan pelayanan hendaknya mempertahankan tingkat etika perkantoran saat memberikan pelayanan kepada peserta didik agar tetap memuaskan serta lebih meningkatkan tingkat pelayanan prima ketika memberikan pelayanan; (2) Kepala Sekolah Menengah Pertama Negeri di Kecamatan Bantur Kabupaten Malang, diharapkan dapat memberikan arahan serta pelatihan terhadap tenaga administrasi sekolah SMP Negeri di Kecamatan Bantur Kabupaten Malang agar mempertahankan penerapan etika perkantoran agar tetap memuaskan serta memberikan wawasan dan pelatihan tentang pelayanan prima secara lebih lanjut; (3) Peneliti lain, hasil penelitian ini diharapkan dapat dijadikan bahan referensi dan dikembangkan lebih lanjut dengan cara mengembangkan pokok permasalahan atau variabelnya, mengubah lokasi penelitian yang berbeda dan jenjang pendidikan yang berbeda.

\section{DAFTAR RUJUKAN}

Barata, A. A. 2004. Dasar-dasar Pelayanan Prima. Jakarta: PT Elex Media Komputindo.

Bratawidjaja, T. W. 1992. Sekretaris Profesional. Jakarta: PT Pusaka Binaman Pressindo.

Dewi, Y. S. 2008. Bekerja Sebagai Sekretaris. Jakarta: Erlangga.

Garnis. 2011. Manajemen Perkantoran (Office Management). (Online), (http://garnismanis.blogspot.com/2011/10/ pentingnya-komunikasi-dalam-kantor.html), diakses 14 Maret 2016.

Gunawan, I. 2012. Kualitas Pelayanan Pendidikan. (Online), (http://masimamgun.blogspot.com/2012/11/kualitaspelayanan-pendidikan.html), diakses 20 Maret 2016.

Irawan, H. 2007. 10 Prinsip Kepuasan Pelanggan: Paradigma Baru Merebut Hati Pelanggan Untuk Memenangkan Persaingan. Jakarta: PT. Elex Media Komputindo.

Kasmir. 2005. Etika Customer Service. Jakarta: PT RajaGrafindo Persada.

Lovelock, C. H \& Wright, L. K. 2007. Manajemen Pemasaran Jasa. Alih Bahasa Agus Widyantoro. Jakarta: Indeks.

Peraturan Menteri Pendidikan Nasional Republik Indonesia Nomor 24 Tahun 2008 tentang Standar Staff Administrasi Sekolah. (Online), (http://sdm.data.kemdikbud.go.id/SNP/dokumen/Permendiknas-No-24 Tahun-2008.pdf), diakses 20 Maret 2016.

Rendang, A. 2013. Makalah Pelayanan Prima (Service Excellent) dalam Keperawatan. (Online),

(http://angelina-rendang.blogspot.com/2013/02/makalah-pelayanan-prima-service_15.html), diakses 14 Maret 2013.

Riady, M. 2008. Filsafat Kuno dan Manajemen Modern. Jakarta: PT Bhuana Ilmu Populer.

Sumarwan, U. 2004. Perilaku Konsumen Teori dan Penerapannya dalam Pemasaran. Bogor: Ghalia Indonesia. 
Tjiptono, F. 2014. Pemasaran Jasa. Yogyakarta: Andi Offset.

Widyaiswara, Z. 2009. Prinsip-Prinsip Pelayanan Prima. (Online), (http://administrasidanmanajemen.blogspot. com/2009/01/prinsip-prinsip-pelayanan-prima.html), diakses 14 Maret 2016.

Wursanto, I. 2006. Kompetensi Sekretaris. Yogyakarta: Andi.

Zulkarnain, W \& Sumarsono, R. B. 2011. Manajemen Perkantoran Pendidikan. Malang: Fakultas Ilmu Pendidikan Universitas Negeri Malang.

Zulkarnain, W \& Sumarsono, R. B. 2014. Manajemen Kantor Sekolah: Konsep dan Strategi Implementasi Bagi Tenaga Administrasi Sekolah. Malang: Fakultas Ilmu Pendidikan Universitas Negeri Malang. 